\title{
Impaired phagocytic activity of neutrophils in patients receiving haemodialysis: the critical role of iron overload
}

\author{
YVES WATERLOT, BRIGITTE CANTINIEAUX, CHANTAL HARIGA-MULLER, \\ EMILIE DE MAERTELAERE-LAURENT, JEAN LOUIS VANHERWEGHEM, PIERRE FONDU
}

\section{Abstract}

The metabolic burst (as measured by the spontaneous and stimulated nitroblue tetrazolium tests), the phagocytosis of heat inactivated bakers' yeast and of Staphylococcus aureus, the killing of Staph aureus, and the myeloperoxidase activity of polymorphonuclear neutrophils were studied in 11 patients receiving maintenance haemodialysis. Of these patients, six were polytransfused and had high serum ferritin concentrations (mean 5940 (SD 2925) $\mu \mathrm{g} / \mathrm{l}$; group 1), and five had normal serum ferritin values (mean 171 (116) $\mu \mathrm{g} / 1$; group 2).

Patients in group 1 had a history of more infectious episodes $(0.167 \mathrm{v} 0.025$ per patient per month) and significantly more genitourinary infections $(p=0.015)$ than those in group 2. Phagocytosis and myeloperoxidase activity were severely reduced in group 1 but normal in group 2. Percentages of neutrophils ingesting one or more particles together with the index of phagocytosis in patients' serum were inversely correlated with serum ferritin concentrations. Four patients in group 1 were treated with desferrioxamine, and after six to 18 weeks of treatment phagocytosis and myeloperoxidase activity had returned to normal in three of them.

These data suggest that in patients receiving haemodialysis iron overload due to multiple transfusions plays an important part in the mechanisms underlying the susceptibility to bacterial

Department of Nephrology, Hôpital Erasme, Free University of Brussels YVES WATERLOT, MD

JEAN LOUIS VANHER WEGHEM, MD, professor

Department of Haematology, Hôpital St Pierre, Free University of Brussels BRIGITTE CANTINIEAUX, MD

CHANTAL HARIGA-MULLER, MD

EMILIE DE MAERTELAERE-LAURENT, MD

PIERRE FONDU, MD, professor

Correspondence to: Dr Yves Waterlot, Service de Médecine Interne, Hôpital St Pierre, 322 Rue Haute, 1000 Bruxelles. infections, mediated at least partially through impaired neutrophil function.

\section{Introduction}

Bacterial infections continue to be a major threat to patients undergoing maintenance haemodialysis. In published reports 14$38 \%$ of all deaths have been attributed to problems related to infection. ${ }^{\prime}$ Studies of phagocytosis and intracellular killing of bacteria by leucocytes from patients receiving haemodialysis are often contradictory, ${ }^{2}$ and even when phagocytosis is shown to be altered the causes are not clear. Uraemia by itself apparently does not change the phagocytic properties of leucocytes.

The frequency of iron overload due to supplementation or multiple transfusions ${ }^{4}$ and the well established relation between haemosiderosis and susceptibility to infection suggest that iron may play a part in the infectious problems of patients receiving haemodialysis. ${ }^{56}$ Among the mechanisms implicated is the possibility that the increased availability of iron stimulates bacterial growth and increases virulence. ${ }^{7}$ Recent studies, however, have emphasised the deleterious effect of excess iron on leucocytes. ${ }^{8}$

We have investigated the possible role of iron overload in the altered function of polymorphonuclear neutrophils in patients receiving maintenance haemodialysis.

\section{Subjects and methods}

From our 72 patients receiving long term haemodialysis we selected six polytransfused patients with high serum ferritin concentrations (group 1; mean serum ferritin concentration 5940 (SD 2925) $\mu \mathrm{g} / \mathrm{l}$ ) and compared them with five matched controls with normal values (group 2; mean concentration $171(116) \mu \mathrm{g} / 1)$. The transfusion scheme aimed at maintaining a packed cell volume of at least $0 \cdot 20$ in patients aged under 60 and of 0.30 in older patients. The mean number of units of red cells transfused was 25 a year in patients in group 1 and 1.5 a year in patients in group 2 . No oral or intravenous supplements of iron were given.

Table 1 gives the clinical and laboratory details of the two groups of patients. No infections were recorded in the four weeks before the study, and no patient was diabetic, had biological evidence of active liver disease, or 


\begin{tabular}{|c|c|c|c|c|c|c|c|c|c|c|c|}
\hline $\begin{array}{l}\text { Case } \\
\text { No }\end{array}$ & $\begin{array}{c}\text { Age } \\
\text { (years) }\end{array}$ & Diagnosis & $\begin{array}{c}\text { Duration of } \\
\text { haemodialysis } \\
\text { (months) }\end{array}$ & $\begin{array}{c}\text { Predialysis } \\
\text { blood urea } \\
\text { nitrogen }(\mathrm{mmol} / \mathrm{l})\end{array}$ & $\begin{array}{l}\text { Residual creatinine } \\
\text { clearance }(\mathrm{ml} / \mathrm{min})\end{array}$ & $\begin{array}{l}\text { Leucocyte count } \\
\left(\times 10^{9} / 1\right)\end{array}$ & $\underset{(\mu \mathrm{g} / \mathrm{l})}{\operatorname{Serum} \text { ferritin }}$ & $\begin{array}{l}\text { Total iron } \\
\text { binding } \\
\text { capacity } \\
(\mu \mathrm{mol} / \mathrm{l})\end{array}$ & $\begin{array}{c}\text { Serum iron } \\
(\mu \mathrm{mol} / \mathrm{l})\end{array}$ & $\begin{array}{l}\text { Serum parathyroid } \\
\text { hormone } \\
(\mu \mathrm{Eq} / \mathrm{ml})\end{array}$ & $\begin{array}{l}\text { Duration of } \\
\text { desferrioxamine } \\
\text { (weeks) }\end{array}$ \\
\hline \multicolumn{12}{|c|}{ Group I } \\
\hline 2 & 54 & $\begin{array}{l}\text { Chronic pyelonephritis, } \\
\text { bilateral nephrectomy }\end{array}$ & 42 & $23 \cdot 2$ & 0 & 7.0 & 8000 & 34.9 & 34.9 & 25 & 15 \\
\hline $\begin{array}{l}3 \\
4 \\
5 \\
6\end{array}$ & $\begin{array}{l}49 \\
44 \\
24 \\
26\end{array}$ & $\begin{array}{l}\text { Chronic pyelonephritis } \\
\text { Chronic glomerulonephritis } \\
\text { Chronic glomerulonephritis } \\
\text { Chronic interstitial nephritis }\end{array}$ & $\begin{array}{l}50 \\
35 \\
40 \\
80\end{array}$ & $\begin{array}{l}35 \cdot 7 \\
35 \cdot 7 \\
32 \cdot 1 \\
32 \cdot 1\end{array}$ & $\begin{array}{l}0.7 \\
0 \\
1.5 \\
0.7\end{array}$ & $\begin{array}{l}7 \cdot 1 \\
8 \cdot 0 \\
5 \cdot 2 \\
4 \cdot 1\end{array}$ & $\begin{array}{l}8300 \\
1700 \\
3040 \\
6100\end{array}$ & $\begin{array}{l}36 \cdot 7 \\
35 \cdot 8 \\
29 \cdot 2 \\
43 \cdot 9\end{array}$ & $\begin{array}{l}35 \cdot 6 \\
34 \cdot 0 \\
27 \cdot 7 \\
43 \cdot 0\end{array}$ & $\begin{array}{l}65 \\
46 \\
76 \\
62\end{array}$ & $\begin{array}{r}17 \\
6 \\
18\end{array}$ \\
\hline $\begin{array}{c}\text { Mean } \\
\text { (SD) }\end{array}$ & $\begin{array}{c}39 \cdot 3 \\
(12 \cdot 2)\end{array}$ & & $\begin{array}{c}52 \cdot 8 \\
(18 \cdot 1)\end{array}$ & $\begin{array}{l}32 \cdot 5 \\
(5 \cdot 1)\end{array}$ & $\begin{array}{c}0.5 \\
(0 \cdot 6)\end{array}$ & $\begin{array}{c}5 \cdot 9 \\
(1 \cdot 6)\end{array}$ & $\begin{array}{c}5940 \\
(2925)\end{array}$ & $\begin{array}{l}35 \cdot 8 \\
(4 \cdot 7)\end{array}$ & $\begin{array}{r}34 \cdot 9 \\
(4 \cdot 9)\end{array}$ & $\begin{array}{l}54 \cdot 5 \\
(17 \cdot 7)\end{array}$ & \\
\hline 7 & 70 & $\begin{array}{l}\text { Chronic glomerulonephritis, } \\
\text { polycystic kidneys }\end{array}$ & 63 & $22 \cdot 5$ & 0 & ${ }_{4 \cdot 0}^{\text {Group } 2}$ & 126 & $34 \cdot 0$ & $9 \cdot 1$ & 65 & \\
\hline $\begin{array}{r}8 \\
9 \\
9 \\
10 \\
11\end{array}$ & $\begin{array}{l}44 \\
59 \\
59 \\
50 \\
48\end{array}$ & $\begin{array}{l}\text { Chronic pyelonephritis } \\
\text { Chronic glomerulonephritis } \\
\text { Chronic glomerulonephritis } \\
\text { Chronic pyelonephritis } \\
\text { Chronic glomerulonephritis }\end{array}$ & $\begin{array}{l}26 \\
36 \\
36 \\
45 \\
40\end{array}$ & $\begin{array}{l}33 \cdot 9 \\
26 \cdot 8 \\
26 \cdot 8 \\
32 \cdot 1 \\
33 \cdot 9\end{array}$ & $\begin{array}{l}0 \\
2 \cdot 0 \\
2 \cdot 0 \\
1 \cdot 0 \\
1 \cdot 5\end{array}$ & $\begin{array}{r}5 \cdot 3 \\
7 \cdot 1 \\
7 \cdot 1 \\
12 \cdot 5 \\
5 \cdot 0\end{array}$ & $\begin{array}{r}250 \\
330 \\
330 \\
40 \\
110\end{array}$ & $\begin{array}{l}44 \cdot 8 \\
39 \cdot 4 \\
39 \cdot 4 \\
34 \cdot 0 \\
32 \cdot 2\end{array}$ & $\begin{array}{r}10 \cdot 7 \\
8 \cdot 4 \\
8 \cdot 4 \\
4 \cdot 3 \\
7 \cdot 3\end{array}$ & $\begin{array}{l}65 \\
58 \\
58 \\
47 \\
64\end{array}$ & \\
\hline \multirow[t]{2}{*}{$\begin{array}{c}\text { Mean } \\
(\text { SD })\end{array}$} & $\begin{array}{c}54 \cdot 8 \\
(10 \cdot 4)\end{array}$ & & $\begin{array}{l}42 \cdot 0 \\
(13 \cdot 6)\end{array}$ & $\begin{array}{l}30 \cdot 0 \\
(5 \cdot 0)\end{array}$ & $\begin{array}{c}0.9 \\
(0.9)\end{array}$ & $\begin{array}{l}6 \cdot 7 \\
(3 \cdot 3)\end{array}$ & $\begin{array}{l}171 \\
(116)\end{array}$ & $\begin{array}{l}36 \cdot 9 \\
(5 \cdot 2)\end{array}$ & $\begin{array}{r}9 \cdot 0 \\
(1 \cdot 3)\end{array}$ & $\begin{array}{l}59 \cdot 8 \\
(7 \cdot 7)\end{array}$ & \\
\hline & \multicolumn{11}{|c|}{$\begin{array}{l}\text { Significance of difference: group } 1 v \text { group 2 } \\
\text { NS }\end{array}$} \\
\hline
\end{tabular}

Conversion: SI to traditional units-Blood urea nitrogen: $1 \mathrm{mmol} / \approx 2 \cdot 8 \mathrm{mg} / 100 \mathrm{ml}$. Total iron binding capacity: $1 \mu \mathrm{mol} / \approx \approx 5 \cdot 6 \mu \mathrm{g} 100 \mathrm{ml}$. Serum iron: $1 \mathrm{~mol} / 2 \approx 5 \cdot 6 \mu \mathrm{g} / 100 \mathrm{ml}$.

was receiving corticosteroids or antibiotics. All episodes of infections during the two years before the study were recorded for both groups.

After the first evaluation of neutrophil function four patients in group 1 (cases 2, 3, 4, and 5) consented to receive desferrioxamine (Desferal) 2 intravenously during each dialysis three times a week and had their neutrophil functions re-evaluated after six to 18 weeks of treatment. Desferrioxamine tests showed no evidence of aluminium overload in these patients.

Thirteen healthy subjects (medical staff) served as controls.

\section{LABORATORY TECHNIQUES}

Blood samples were taken into sterile tubes before systemic heparinisation and before dialysis. Neutrophils were obtained from $20 \mathrm{ml}$ heparinised blood samples by a modification of Boyum's method. ${ }^{9}$ Erythrocytes were haemolysed and neutrophils isolated by five differential centrifugations followed by resuspension in Hanks's balanced salt solution containing $0 \cdot 1 \%$ gelatin. Total and differential leucocyte counts were determined. The leucocyte pellets finally obtained were suspended to concentrations of $5 \times 10^{9}$ and $10 \times 10^{9}$ polymorphonuclear neutrophils/l. Spontaneous reduction of nitroblue tetrazolium was studied by a modified version of the method of Park et al..$^{10}$ Equal volumes of the suspension of $10 \times 10^{9}$ neutrophils/1 and of the nitroblue tetrazolium solution were mixed in an agitator for 30 minutes at $37^{\circ} \mathrm{C}$ and the neutrophils removed by centrifugation. Smears were stained by May-Grünwald-Giemsa and 200 neutrophils counted to establish the percentage of positive cells.

The stimulated nitroblue tetrazolium test was adapted from the method of Baehner and Nathan, as modified by Holmes et al. ${ }^{11}$ The metabolic burst in neutrophils was stimulated by phagocytosis of latex particles in the presence of reduced nicotinamide adenine dinucleotide in the medium. Phagocytosis was studied using particles of bakers' yeast and bacteria (Staphylococcus aureus). Bakers' yeast was heat inactivated and suspended at $50 \times 10^{9}$ particles $/ 1$ in $0.9 \%$ sodium chloride. Staph aureus $42 \mathrm{~d}$ was grown for 18 hours in brain heart infusion broth (Difco, Detroit, USA) and suspended at $300 \times 10^{9}$ colony forming units (CFU)/l. The bacteria were opsonised for 10 minutes in pooled normal human serum or in patients' serum. ${ }^{12}$ After opsonisation the serum was removed by centrifugation and the bacteria suspended to a concentration of $50 \times 10^{9} \mathrm{CFU} / \mathrm{l}$ in Hanks's balanced salt solution.

For the study of phagocytosis equal volumes of yeast particles and suspension of neutrophils in normal or patients' serum were mixed in polypropylene phials ( $25 \%$ of serum in the medium $)^{13}$; opsonised Staph aureus, in normal or patients' serum, were mixed with a suspension of polymorphonuclear neutrophils in Hanks's balanced salt solution (vol 1:1). The final particle to phagocyte ratio was 10:1. The mixtures were incubated under rotation at $37^{\circ} \mathrm{C}$ for 30 minutes, after which phagocytosis was stopped by centrifugation in ice. Droplets of the sediment were spread on slides. These were stained by May-Grünwald-Giemsa and 200 neutrophils examined to establish the percentage ingesting one or more particles and to calculate the mean number of particles phagocytosed by neutrophils (index of phagocytosis).

The assay for intracellular killing was adapted from that of Leijh $e t$ al. ${ }^{14}{ }^{15}$ Polymorphonuclear neutrophils were allowed to phagocytose opsonised
Staph aureus (in patients' or normal serum) for seven minutes at $37^{\circ} \mathrm{C}$. The final bacteria to neutrophil ratio was $5: 1$. Non-ingested bacteria were removed by three washes of neutrophils. Those neutrophils containing ingested bacteria were resuspended in $10 \%$ serum and reincubated at $37^{\circ} \mathrm{C}$ under rotation. After 60 and 120 minutes intracellular killing was stopped by centrifugation at $0^{\circ} \mathrm{C}$ and the cells lysed by adding $1.0 \mathrm{ml}$ distilled water. The percentage of killed bacteria at 60 and 120 minutes was established by counting colony forming units on Petri plates.

Myeloperoxidase activity was estimated by scoring myeloperoxidase activity stained neutrophils; the myeloperoxidase score was determined by counting 100 consecutive neutrophils and grading the intensity of staining in each from 0 to $4+.^{16}$

Perls' test was carried out on buffy coat smears from three patients in group 1 (serum ferritin concentrations 1700,8000 , and $8300 \mu \mathrm{g} / \mathrm{l}$ ).

\section{STATISTICAL ANALYSIS}

Differences in the functioning of polymorphonuclear neutrophils and in clinical characteristics between patients with iron overload and those with normal iron stores were analysed by Student's $t$ test; when there was inequality of variances, however, the Mann-Whitney $U$ test was used instead. The relation between serum ferritin concentrations and the phagocytosis index and percentage of neutrophils ingesting one or more particles was tested by the correlation coefficient of Pearson. Fisher's exact test was used to compare the incidences of infectious episodes in the two groups.

\section{Results}

The two groups of patients were comparable in age, duration of haemodialysis, diagnosis, predialysis blood urea nitrogen concentration, residual creatinine clearance, and parathyroid hormone concentration (table I). Those in group 1 (high serum ferritin concentrations), however, had had more infectious episodes $(24 ; 168$ patient months) than those in group 2 (three; 140 patient months). Furthermore, significantly more genitourinary infections had been documented in group $1(p=0.015$; table II). That the infectious episodes were often serious is exemplified by the following three cases.

TABLE II-Incidences of different types of infections in the two groups of patients during 24 months before study. Result expressed as numbers of patients (numbers of episodes given in parentheses)

\begin{tabular}{lccccc}
\hline & \multicolumn{5}{c}{ Infection } \\
\cline { 2 - 6 } & Genitourinary & $\begin{array}{c}\text { Septicaemia } \\
\text { (Escherichia } \\
\text { coli) }\end{array}$ & $\begin{array}{c}\text { Kidney lodge } \\
\text { abscess }\end{array}$ & Bronchopneumopathy & Cholecystitis \\
\hline Group 1 (n=6) & $6(17)^{\star}$ & $3(3)$ & $1(1)$ & $2(2)$ & $1(1)$ \\
Group 2 $(n=5)$ & $1(1)^{\star}$ & 0 & $0(2)$ & $2(2)$ & 0 \\
\hline
\end{tabular}

* Significance of difference $p=0 \cdot 015$. 
Case 1-This patient developed septicaemia and cutaneous cellulitis due to Escherichia coli after prostatitis. A year later there was a recurrence of the $E$ coli septicaemia complicated by the adult respiratory distress syndrome, and the patient died.

Case 2-This woman underwent a nephrectomy for pyonephrosis secondary to necrotising papillitis. One year later she developed an abscess with $E$ coli at the site of the nephrectomy which necessitated surgical drainage.

Case 3-This patient suffered multiple episodes of symptomatic urinary tract with serum ferritin values (percentage of neutrophils ingesting $\geqslant 1$ particle: $\mathrm{r}=-0.72, \mathrm{p}<0.05, \mathrm{n}=11$; phagocytosis index: $\mathrm{r}=-0.65, \mathrm{p}<0.05, \mathrm{n}=11$ ). Phagocytosis of yeast in patients' serum was also inversely correlated with ferritin values (percentage of neutrophils ingesting $\geqslant 1$ particle: $r=-0 \cdot 76$, $\mathrm{p}<0.01, \mathrm{n}=11$; phagocytosis index: $\mathrm{r}=-0.72, \mathrm{p}<0.05, \mathrm{n}=11$ ) (fig 1). No other variable was correlated with the serum ferritin concentration.

The four patients in group 1 who were given desferrioxamine showed no change in serum ferritin values on transferrin saturation. After six to 18

\begin{tabular}{|c|c|c|c|c|}
\hline & $\begin{array}{c}\text { Group I ( } n=6 ; \\
\text { high ferritin values) }\end{array}$ & $\begin{array}{c}\text { Group } 2(n=5 ; \\
\text { normal ferritin values })\end{array}$ & $\begin{array}{c}\text { Significance of } \\
\text { difference between } \\
\text { groups } 1 \text { and } 2\end{array}$ & $\begin{array}{l}\text { Healthy controls } \\
\qquad(\mathrm{n}=13)\end{array}$ \\
\hline \multicolumn{5}{|l|}{$\begin{array}{l}\text { Nitroblue tetrazolium test ( } \% \text { of } \\
\text { positive cells): }\end{array}$} \\
\hline $\begin{array}{l}\text { Spontaneous } \\
\text { Stimulated }\end{array}$ & $\begin{array}{l}27(13 \cdot 0) \\
38(26 \cdot 1)\end{array}$ & $\begin{array}{l}28(9 \cdot 0) \\
44(12 \cdot 4)\end{array}$ & $\begin{array}{l}\text { NS } \\
\text { NS }\end{array}$ & $\begin{array}{l}21(18 \cdot 0) \\
41(24 \cdot 1)\end{array}$ \\
\hline \multicolumn{5}{|l|}{$\begin{array}{l}\text { Phagacytosis index (No of } \\
\text { particles ingested by } \\
\text { neutrophils): }\end{array}$} \\
\hline $\begin{array}{l}\text { Staph } \\
\text { aureus }\left\{\begin{array}{l}\text { Normal serum } \\
\text { Patients' serum }\end{array}\right.\end{array}$ & $\begin{array}{l}3 \cdot 6(1 \cdot 07) \\
2 \cdot 7(1 \cdot 34)\end{array}$ & $\begin{array}{l}7 \cdot 1(2 \cdot 35) \\
7 \cdot 2(2 \cdot 56)\end{array}$ & $\begin{array}{l}\mathrm{p}<0.001 \\
\mathrm{p}<0.01\end{array}$ & $6.5(1.80)$ \\
\hline Yeast $\left\{\begin{array}{l}\text { Normal serum } \\
\text { Patients' serum }\end{array}\right.$ & $\begin{array}{l}2 \cdot 6(0 \cdot 9) \\
2 \cdot 2(0 \cdot 49)\end{array}$ & $\begin{array}{l}4 \cdot 2(1 \cdot 00) \\
4 \cdot 2(1 \cdot 16)\end{array}$ & $\begin{array}{l}\mathrm{p}<0.02 \\
\mathrm{p}<0.05\end{array}$ & $4.4(1.74)$ \\
\hline \multicolumn{5}{|l|}{$\begin{array}{l}\text { Percentage neutrophils ingesting } \\
\geqslant 1 \text { particle: }\end{array}$} \\
\hline $\begin{array}{l}\text { Staph } \\
\text { aureus }\left\{\begin{array}{l}\text { Normal serum } \\
\text { Patients' serum }\end{array}\right.\end{array}$ & $\begin{array}{l}58(10 \cdot 9) \\
41(17 \cdot 6)\end{array}$ & $\begin{array}{l}76(9 \cdot 8) \\
76(11 \cdot 9)\end{array}$ & $\begin{array}{l}p<0.02 \\
\mathbf{p}<0.01\end{array}$ & $75(19 \cdot 4)$ \\
\hline Yeast $\left\{\begin{array}{l}\text { Normal serum } \\
\text { Patients' serum }\end{array}\right.$ & $\begin{array}{l}59(16 \cdot 5) \\
60(10 \cdot 3)\end{array}$ & $\begin{array}{l}88(6 \cdot 3) \\
91(4 \cdot 7)\end{array}$ & $\begin{array}{l}\mathrm{p}<0.05 \\
\mathrm{p}<0.001\end{array}$ & $99(1 \cdot 9)$ \\
\hline 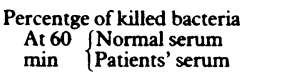 & $\begin{array}{l}61(12 \cdot 1) \\
54(7 \cdot 4)\end{array}$ & $\begin{array}{l}56(5 \cdot 8) \\
57(10 \cdot 6)\end{array}$ & $\begin{array}{l}\text { NS } \\
\text { NS }\end{array}$ & $69(23 \cdot 5)$ \\
\hline $\begin{array}{l}\text { At } 120\left\{\begin{array}{l}\text { Normal serum } \\
\text { min }\end{array} \text { Patients' serum }\right.\end{array}$ & $\begin{array}{l}81(7 \cdot 4) \\
77(5 \cdot 8)\end{array}$ & $\begin{array}{l}78(10 \cdot 3) \\
77(10 \cdot 1)\end{array}$ & NS & $81(18 \cdot 4)$ \\
\hline Myeloperoxidase activity score & $282 \cdot 7(54 \cdot 05)$ & $354 \cdot 0(37 \cdot 77)$ & $p<0.05$ & $351 \cdot 3(17 \cdot 5)$ \\
\hline
\end{tabular}

TABLE IV-Results of polymorphonuclear neutrophil function studies before and after desferrioxamine treatment in four patients

\begin{tabular}{|c|c|c|c|c|c|c|c|c|c|}
\hline & \multicolumn{4}{|c|}{ Before treatment } & \multicolumn{4}{|c|}{ After treatment } & \multirow[t]{2}{*}{$\begin{array}{l}\text { Eight weeks after } \\
\text { interruption of } \\
\text { desferrioxamine } \\
\text { in case } 3\end{array}$} \\
\hline & Case 2 & 3 & 4 & 5 & 2 & 3 & 4 & 5 & \\
\hline \multicolumn{10}{|l|}{$\begin{array}{l}\text { Phagocytosis index (No of } \\
\text { particles ingested by } \\
\text { neutrophils): }\end{array}$} \\
\hline $\begin{array}{l}\text { Staph INormal serum } \\
\text { aureus TPatients' serum }\end{array}$ & $\begin{array}{l}4 \cdot 8 \\
3 \cdot 1\end{array}$ & $\begin{array}{l}2.5 \\
0.5\end{array}$ & $\begin{array}{l}2 \cdot 6 \\
2 \cdot 2\end{array}$ & $\begin{array}{l}2.9 \\
2.9\end{array}$ & $\begin{array}{l}7.6 \\
7.8\end{array}$ & $\begin{array}{l}6 \cdot 9 \\
4 \cdot 4\end{array}$ & $\begin{array}{l}5 \cdot 2 \\
4 \cdot 6\end{array}$ & $\begin{array}{l}1 \cdot 2 \\
2 \cdot 6\end{array}$ & $\begin{array}{l}1 \cdot 8 \\
2 \cdot 3\end{array}$ \\
\hline Yeast $\left\{\begin{array}{l}\text { Normal serum } \\
\text { Patients' serum }\end{array}\right.$ & $\begin{array}{l}3 \cdot 5 \\
2 \cdot 1\end{array}$ & $\begin{array}{l}1 \cdot 3 \\
1.4\end{array}$ & $\begin{array}{l}1 \cdot 9 \\
2 \cdot 3\end{array}$ & $\begin{array}{l}2 \cdot 1 \\
2 \cdot 2\end{array}$ & $\begin{array}{l}4 \cdot 6 \\
4 \cdot 7\end{array}$ & $\begin{array}{l}3 \cdot 2 \\
3 \cdot 9\end{array}$ & $\begin{array}{l}3 \cdot 5 \\
3.4\end{array}$ & $\begin{array}{l}1 \cdot 1 \\
2 \cdot 5\end{array}$ & $\begin{array}{l}1 \cdot 8 \\
2 \cdot 6\end{array}$ \\
\hline \multicolumn{10}{|l|}{$\begin{array}{l}\text { Percentage of neutrophils } \\
\text { ingesting } \geqslant 1 \text { particle: }\end{array}$} \\
\hline $\begin{array}{l}\text { Staph } \\
\text { aureus }\left\{\begin{array}{l}\text { Normal serum } \\
\text { Patients' serum }\end{array}\right.\end{array}$ & $\begin{array}{l}73 \\
54\end{array}$ & $\begin{array}{r}47 \\
6\end{array}$ & $\begin{array}{l}51 \\
43\end{array}$ & $\begin{array}{l}51 \\
49\end{array}$ & $\begin{array}{l}84 \\
88\end{array}$ & $\begin{array}{l}54 \\
57\end{array}$ & $\begin{array}{l}67 \\
75\end{array}$ & $\begin{array}{l}15 \\
33\end{array}$ & $\begin{array}{l}59 \\
67\end{array}$ \\
\hline Yeast $\left\{\begin{array}{l}\text { Normal serum } \\
\text { Patients' serum }\end{array}\right.$ & $\begin{array}{l}78 \\
68\end{array}$ & $\begin{array}{l}42 \\
55\end{array}$ & $\begin{array}{l}61 \\
73\end{array}$ & $\begin{array}{l}49 \\
51\end{array}$ & $\begin{array}{l}98 \\
94\end{array}$ & $\begin{array}{l}59 \\
59\end{array}$ & $\begin{array}{l}66 \\
51\end{array}$ & $\begin{array}{l}59 \\
69\end{array}$ & $\begin{array}{l}55 \\
15\end{array}$ \\
\hline Myeloperoxidase activity score & 341 & 224 & 235 & 252 & 374 & 318 & 300 & 408 & 313 \\
\hline Weeks of treatment & & & & & 15 & 17 & 6 & 18 & \\
\hline
\end{tabular}

infection, sometimes with septicaemia due to $E$ coli not eradicable despite prolonged treatment with appropriate antibiotics.

Table III shows the results of the neutrophil function studies in the two groups of patients and in the 13 healthy controls. The reduction of nitroblue tetrazolium as measured by the spontaneous and stimulated tests was not significantly different between the two groups of patients. The index of phagocytosis and the percentage of neutrophils phagocytosing at least one particle were, however, significantly lower in group 1 for both yeast and Staph aureus. In these patients phagocytosis of Staph aureus was improved in the presence of normal serum but remained low in comparison with the controls. The difference was significant between normal serum and patients' serum in the percentage of neutrophils ingesting at least one particle $(p \leqslant 0.05)$ and at the limit of significance for the phagocytosis index $(p \leqslant 0 \cdot 10)$. Bacterial killing was normal in both groups.

The myeloperoxidase activity score was lower in group 1 than in group 2 $(p \leqslant 0.05)$. Perls' reaction was tested in three patients with iron overload and showed iron in over $5 \%$ of their neutrophils. In healthy controls no neutrophils were Perls' test positive.

Phagocytosis of Staph aureus in patients' serum was inversely correlated weeks of treatment, however, all but one (case 5) had a normal phagocytosis index (table IV; fig 2). In case 3 administration of desferrioxamine was interrupted and neutrophil function measured four weeks later. A profound alteration of the phagocytosis of particles was found.

Of particular interest was case 2 . In this patient phagocytosis returned to normal with desferrioxamine but she developed high grade fever with signs of peritonitis; laparotomy showed terminal ileitis with mesenteric purulent adenitis. Cultures of pus and blood grew Yersinia enterocolitica; the patient was treated with co-trimoxazole and recovered.

\section{Discussion}

In the absence of hepatic cytolysis the serum ferritin concentration is generally considered to be a good indicator of iron stores. ${ }^{17}$ Nevertheless, it has recently been reported that part of the iron in the plasma of patients with thalassaemia major may not be bound to transferrin. This abnormal serum iron fraction was chelatable by 


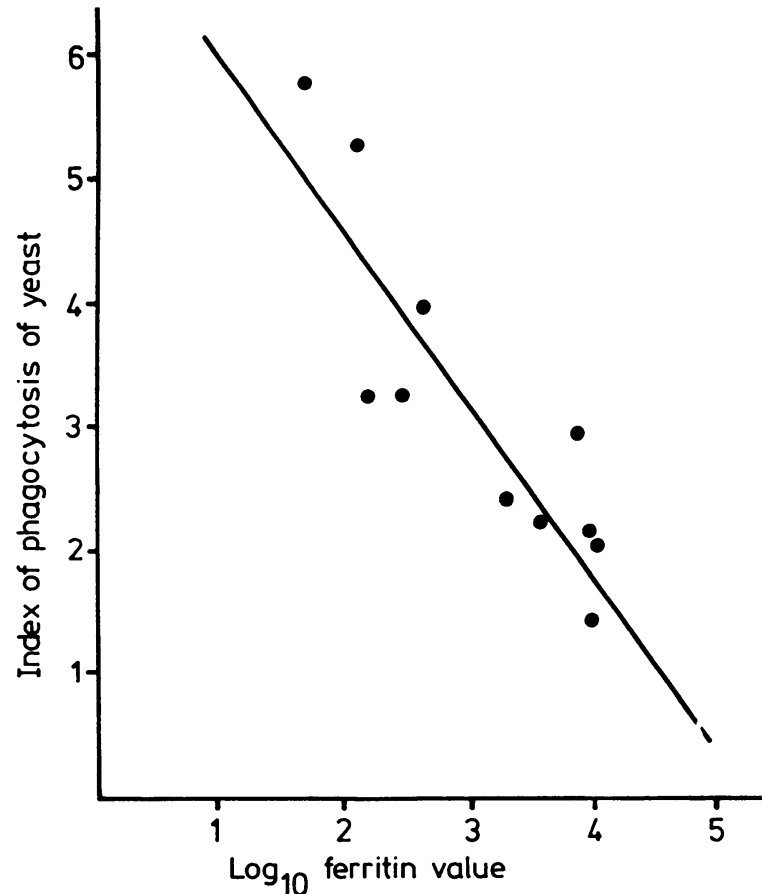

FIG 1-Relation between serum ferritin concentrations and index of phagocytosis of yeast in patients' serum.

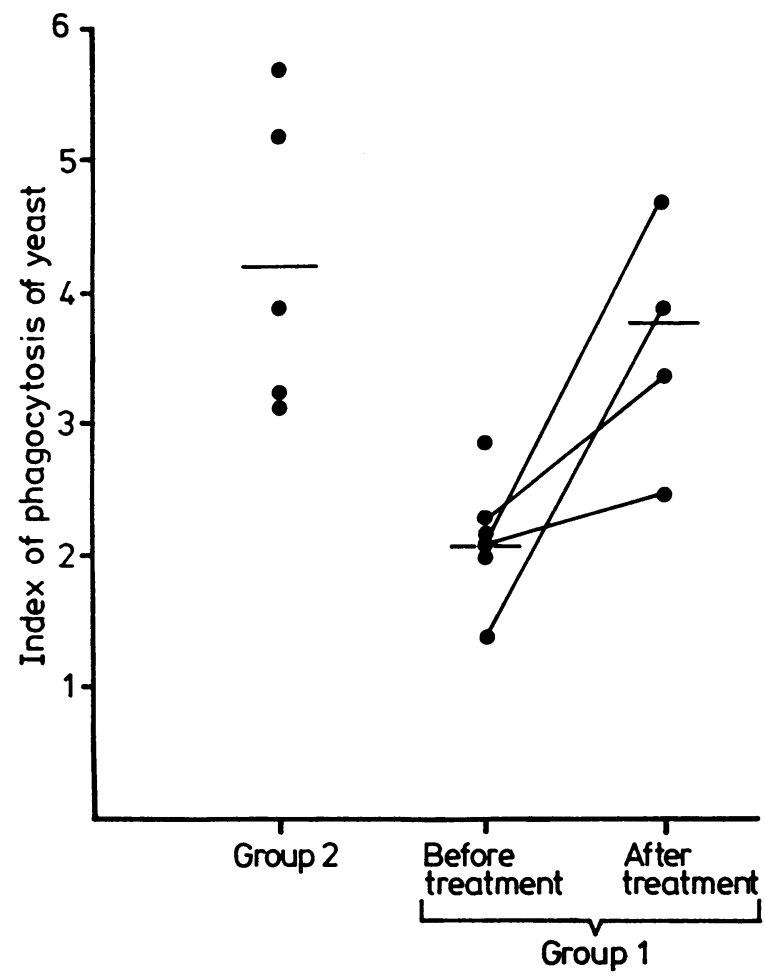

FIG 2-Index of phagocytosis of yeast in serum of patients in group 2 and in group 1 before and after desferrioxamine treatment. Bars are means.

exogenous transferrin or by desferrioxamine and was associated with high serum ferritin concentrations; the transferrin iron saturation was over $80 \%$ in these cases. ${ }^{18} 19$

Although this unbound fraction of iron was not sought in our group 1, we hypothetise that if it were present it might be implicated in the alteration of neutrophil phagocytosis and myeloperoxidase activity. The negative correlation between phagocytosis in patients' serum and the ferritin concentration would support this hypothesis. That excess iron accumulates in neutrophils of polytransfused patients may be shown by Perls' test, but the chemical nature of the iron and the mechanism of its penetration into these cells are unclear.

The toxicity of iron for neutrophils may be due to the formation of excess oxidant radicals. ${ }^{20}$ These radicals might alter phagocytosis through peroxidation of neutrophil membrane lipids. ${ }^{2122}$ The toxic effect of iron on myeloperoxidase was described in $1959 .{ }^{23}$ Despite the deficiency of myeloperoxidase activity observed in group 1 the killing of Staph aureus was normal, possibly because of excess oxidant radicals formed in the presence of iron.

The complete restoration of normal phagocytotic activity in three out of four patients treated with desferrioxamine may be explained by the chelation of the toxic iron by this agent. This hypothesis is supported by our observation in case 3 ; in this patient interruption of treatment with desferrioxamine resulted in an alteration of phagocytosis previously returned to normal by desferrioxamine.

Our data confirm recent in vitro studies in which neutrophil phagocytosis was altered in an iron enriched medium and corrected by desferrioxamine added to the medium. ${ }^{24}$ The use of desferrioxamine in patients with iron overload may, however, be hazardous, as shown by our case 2 . Desferrioxamine may precipitate severe $Y$ enterocolitica infections by acting as a siderophore for this species and providing the iron necessary for virulence and growth. ${ }^{25}$

Our study shows that blood transfusions must be administered with the utmost caution in dialysis centres and that systematic iron treatment should be avoided owing to the risk of haemosiderosis and the consequent deleterious effect on the defences against infection, mediated at least partially through impairment of neutrophil function.

We are indebted to Mrs Catherine Primo for technical work, Mr Bob Schuyler for help in translating the manuscript, and Mrs Maria Peirlinckx for typing.

\section{References}

1 Montgomerie JZ, Kalmansar GM, Guze LB. Renal failure and infection. Medicine 1968;47:1. 2 Goldblum SE, Reed WP. Host defenses and immunologic alterations associated with chronic haemodialysis. Ann Intern Med 1980;93:597-613.

3 Nelson H, Armrod DJ, Miller TE. Host immune status in uremia. IV. Phagocytosis and inflammatory response in vivo. Kidney Int 1983;23:312-9.

4 Ali M, Fayemi O, Rigolosi R, et al. Hemosiderosis in hemodialysis patients. fAMA 1980;244: 343-5.

5 Murray MJ, Murray AB, Murray MB, Murray CJ. The adverse effect of iron repletion on the course of certain infections. BrMed $\mathcal{F}$ 1978;ii: 1113 -5.

6 Melby K, Slørdahl S, Gutteber GTJ, Nordbø SA. Septicaemia due to Yersinia enterocolitica after oral overdoses of iron. BrMed 7 1982;285:467-8.

7 Weinberg ED. Iron and infection. Microbiol Rev 1978:42:45-66.

8 Sweder van Asbeck B, Marx JJ, Struyvenberg A, et al. Effect of iron (III) in the presence of various ligands on the phagocytic and metabolic activity of human polymorphonuclear leukocytes. I Immunol 1984;132:851-6.

9 Boyum A. Isolation of mononuclear cells and granulocyres from human blood. Scand f Clin Lab Invest 1968;97 (suppl):77-89.

0 Park BH, Fikrig SM, Smithwich EM. Infection and nitroblue tetrazolium reduction in neutrophils. A diagnostic aid. Lancet 1968 ;ii: 532 .

11 Holmes B, Quie PG, Windhorst DB, Good RA. Fatal granulomatous disease of childhood. Lancet 1966;i: 1225

12 Leijh PC, Van der Barselaar MT, Dubbeldeman-Rempt I, Van Furth R. Kinetics of phagocytosis of Staphylococcus aureus and Escherichia coli by human granulocytes. Immunology 1979;37:453-65:

13 Brandt L. Studies on the phagocytic activity of neutrophilic leukocytes. Scand $\mathcal{J}$ Haematol 1967;suppl 2:7-34.

14 Leijh PC, Van der Barselaar MT, Daha MR, Van Furth R. Participation of immunoglobulins and complement components in the intracellular killing of Staphylococcus aureus and Escherichia coli by human granulocytes. Infect Immun 1981;33:717-24.

15 Leiih PC, Van der Barselaar MT, Van Zwet TL, Dubbeldeman-Rempt I, Van Furth R. Kinetics of intracellular killing of Staphylococcus aureus and Escherichia coli. Eur $f$ Immunol 1980;10:750-7.

16 Kitahara $M$, Simonian Y, Eyre HJ. Neutrophil myeloperoxidase: a simple reproducible technique to determine activity. $\mathcal{F}$ Lab Clin Med 1979;93:232-7.

17 Moreb J, Poportzer MM, Friedlaender MM, et al. Evaluation of iron status in patients on chronic hemodialysis: relative usefulness of bone marrow hemosiderin, serum ferritin, transferrin saturation, mean corpuscular volume and red cell protoporphyrin. Nephron 1983;35:196-200.

18 Hershko C, Graham G, Bates GW, Rachmilewitz EA. Non specific serum iron in thalassaemia: an abnormal serum iron fraction of potential toxicity. Br J Haematol 1978:40:255-63.

19 Anuwatanakulchai M, Pootrakul P, Thuvasethakul P, Wasi P. Non transferrin plasma iron in $\beta$ thalassaemia/Hb E and haemoglobin $\mathrm{H}$ diseases. Scand $f$ Haematol 1984; 32: 153-8.

20 Koppenol WM, Butler J, Van Leeuwen JW. The Haber-Weiss cycle. Photochem Photobiol 1978;28:655.

21 Pryor WA. The formation of free radicals and the consequences of their reaction in vivo. Photochem Photobiol 1978;28:787.

22 Aisen P. Current concepts in iron metabolism. Clin Haematol 1982:11:241-57.

23 Schultz J, Rosenthal S. Iron (II) inactivation of myeloperoxidase. F Biol Chem 1959;244:2486-90.

24 Sweder van Asbeck B, Marcx JJ, Struyvenberg A, et al. Desferrioxamine enhances phagocytic function of human polymorphonuclear leukocytes. Blood 1984;63:714-20.

25 Robins-Browne RM, Prpic JK. Desferrioxamine and systemic yersiniosis. Lancet 1983;ii: 1372.

(Accepted 16 May 1985) 